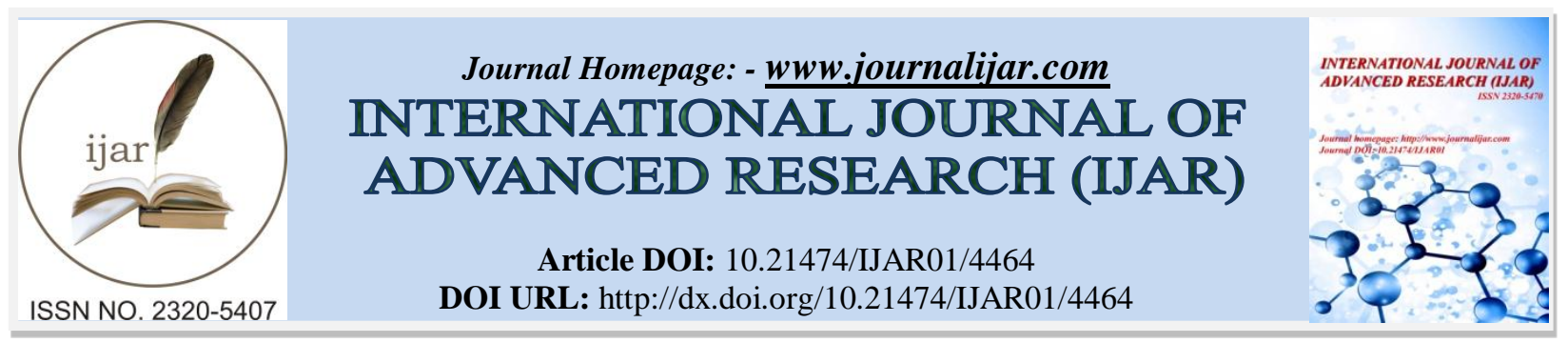

RESEARCH ARTICLE

\title{
CONSTRUCTION OF ALGAL FUEL CELL FOR PRODUCTION OF ELECTRICITY USING SCENEDESMUS SPP.
}

\section{Qasim Muhammad Abdulhussein Altaher ${ }^{1}$, Kadhum Sabah Naser Alshekhmoham ${ }^{1}$, Fadhil Kayoon Naser ${ }^{1}$, Hemal Makani ${ }^{2}$ and Asha Salunke ${ }^{2}$}

1. Department of Environmental Science, Savitribai Phule Pune University, Ganeshkhind Road, Pune - 411007, Maharashtra, India.

2. BioEra Life Sciences Pvt. Ltd., BioEra Park, S. No. 125, Mumbai-Bangalore Highway, Tathawade, Pune - 411 033, Maharashtra, India.

\section{Manuscript Info}

Manuscript History

Received: 12 April 2017

Final Accepted: 14 May 2017

Published: June 2017

\section{Key words:-}

Microbial fuel cell, Algal fuel cell, Bioenergy, Biofuels, Scenedesmus spp

\section{Abstract}

The critical situation of limited supply of energy resources has led to the search of an eco-friendly, alternative fuel. Microbial fuel cell (MFC) is rapidly evolving technology and can be looked upon to help or partially overcome the challenges of fuel crisis. In the present study Scenedesmus spp was isolated and characterized. The growth conditions were modified to increase their hydrogen and oxygen production. The maximum Chlorophyll content was observed to be $9.62 \mu \mathrm{g} / \mathrm{ml}$ and the maximum potential difference observed was 83 $\mathrm{mV}$ on $24^{\text {th }}$ day.

Copy Right, IJAR, 2017,. All rights reserved.

\section{Introduction:-}

Energy drives human life and it is extremely crucial for continued human development. Over the last two decades renewable energy resources like solar and wind energy systems have experienced rapid growth and the cost of energy generated from these renewable resources is significantly coming down. The main challenge with the renewable energy is the intermittency requiring major storage or large-scale integration and the environmental interdependency of these devices to perform to their fullest strength. For e.g. the solar energy generation depends on intensity of light, which changes throughout the day and throughout the year depending on the seasonal variations (Olle and Villy, 2016).

In order to overcome these problems and generate electricity in a sustainable manner Fuel cells are looked upon as a powerful alternative. Fuel cell is an electrochemical conversion device that combines Hydrogen and Oxygen to form water and releases an electron which is captured and made to circulate in an external electrical circuit; this generates electricity if the process runs continuously. A fuel cell system can be used in any application with the right selection of power electronics circuits (Ali et al., 2014). The continuous supply and storage of Hydrogen and Oxygen becomes the only barrier in the development of the fuel cell based devices (Dimitris and Maria, 2016).

Algal fuel cells provide a solution to the Hydrogen and Oxygen generation. It is known from literature that all photosynthetic organisms including algae split the water molecule to give out Oxygen during Photolysis of water. This property of algae can be used to make Oxygen in cathode chamber of fuel cell. In addition, some algal species are known to produce Hydrogen during fermentative photosynthetic pathway which is induced upon Sulphur deprivation conditions. These properties of algal species can be used to make Hydrogen in anode chamber of the 
Fuel cell (Chang et al., 2015, Gaffron, 1939). The present study focused on constriction of algal fuel cell using an algal species Scenedesmus which produces Oxygen as well as Hydrogen when grown separately with different culture conditions.

\section{Materials and Method:-}

Sample collection for Algae:-

Approximately $250 \mathrm{ml}$ of water sample was collected in sample collection bottles from a fish pond and Mula River, Pune, India. Samples were then transferred to the laboratory and were examined under the microscope to check presence of any algal cells.

\section{Enrichment of Algae:-}

For enrichment of algal cells the collected water samples were inoculated in BG11 medium, and incubated in bright sunlight. After incubation period of approximately 1 week the media was observed under microscope for possible growth of algal cells (Stanier et al., 1971).

\section{Growth Analysis:-}

Growth analysis was followed by estimation of total chlorophyll content. Algal cells were pelleted down by centrifuging $5 \mathrm{ml}$ of the culture suspension at $5000 \mathrm{rpm}$ for $5 \mathrm{~min}$. The cells were resuspended into $500 \mu \mathrm{l}$ of Methanol. The mixture was vigoursly vortexed in order to break open the algal cells and release of Chlorophyll content. The extraction mixture was kept at $4{ }^{\circ} \mathrm{C}$ to allow complete extraction. After 24 hours, the cell debris was separated from the suspension by centrifugation. The supernatant was read at $666 \mathrm{~nm}$ and $653 \mathrm{~nm}$ using a spectrophotometer and pure methanol as blank (Dere et al., 1998). Chlorophyll content of the algal extract was calculated using following formulae:

$\mathrm{Ca}=15.65 \mathrm{~A}_{666}-7.34 \mathrm{~A}_{653}$

$\mathrm{Cb}=27.65 \mathrm{~A}_{653}-11.21 \mathrm{~A}_{666}$

Where,

$\mathrm{Ca}=$ Chlorophyll A,

$\mathrm{Cb}=$ Chlorophyll B in $\mu \mathrm{g} / \mathrm{ml}$

Total Chlorophyll $=\mathrm{Ca}+\mathrm{Cb}$

\section{Optimization of media for Oxygen production:-}

BG11 media was used for growing the algal cells to produce Oxygen.

\section{Optimization of media for Hydrogen production:-}

For Hydrogen production the BG11 medium was modified and was converted to Sulfur deprived BG11 medium (Das and Sharma, 2015).

\section{Screening for Oxygen production:-}

The enriched algal culture was screened for Oxygen production by using the Janus Green B. The test was carried out by mixing the $1 \%$ solution of Janus Green B $(100 \mu \mathrm{l})$ in the culture suspension $(5 \mathrm{ml})$ and incubated in presence of light. The tube was observed after regular intervals of time for colour change (Berlin and Reca, 1967).

\section{Screening for Hydrogen production:-}

Hydrogen production was screened by Methylene Blue Reduction Test (MBRT). The algal suspension which was grown in Suphur deprived environment was checked for its Hydrogen production (reducing) capacity. The algal suspension $(5 \mathrm{ml})$ was mixed with $1 \%$ Methylene blue dye $(100 \mu \mathrm{l})$ and then the tube was incubated in bright sunlight. The tube was checked for colour change at regular intervals of time (Chatterjee et al., 2006).

\section{Construction of Algal fuel cell:-}

Algal fuel cell was constructed using algal cultures producing Hydrogen and Oxygen. Algae grown in sulphur deprived media were able to produce Hydrogen and hence the culture suspension was added to a wide mouthed glass bottle and was labeled as anode chamber. A Copper electrode was dipped into the suspension and connected to a wire externally. The algal cells grown in BG11 medium were able to produce Oxygen. This suspension of cells was added to another glass bottle. A Copper electrode was inserted in the chamber. Both the bottles were connected via a salt bridge. Salt bridge was constructed by dissolving agar in 1N KCL and solidifying the molten agar KCL 
mixture into a short glass tube. After solidifying the salt bridge was used to connect the fuel cell. A multimeter was connected in-line to check the electricity production (Williams and Bees, 2013).

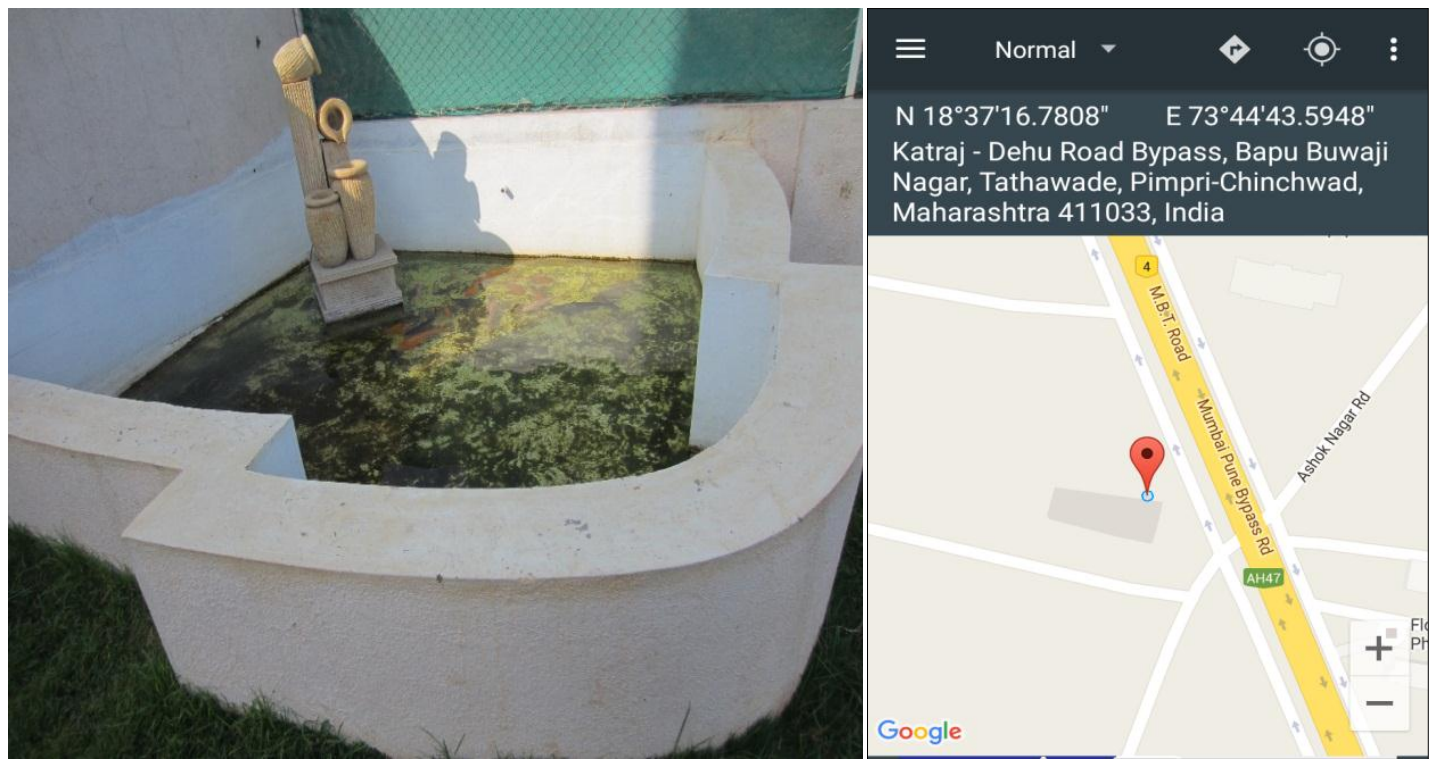

Figure 1:- Water sample collection site at Tathawade - Fish pond.
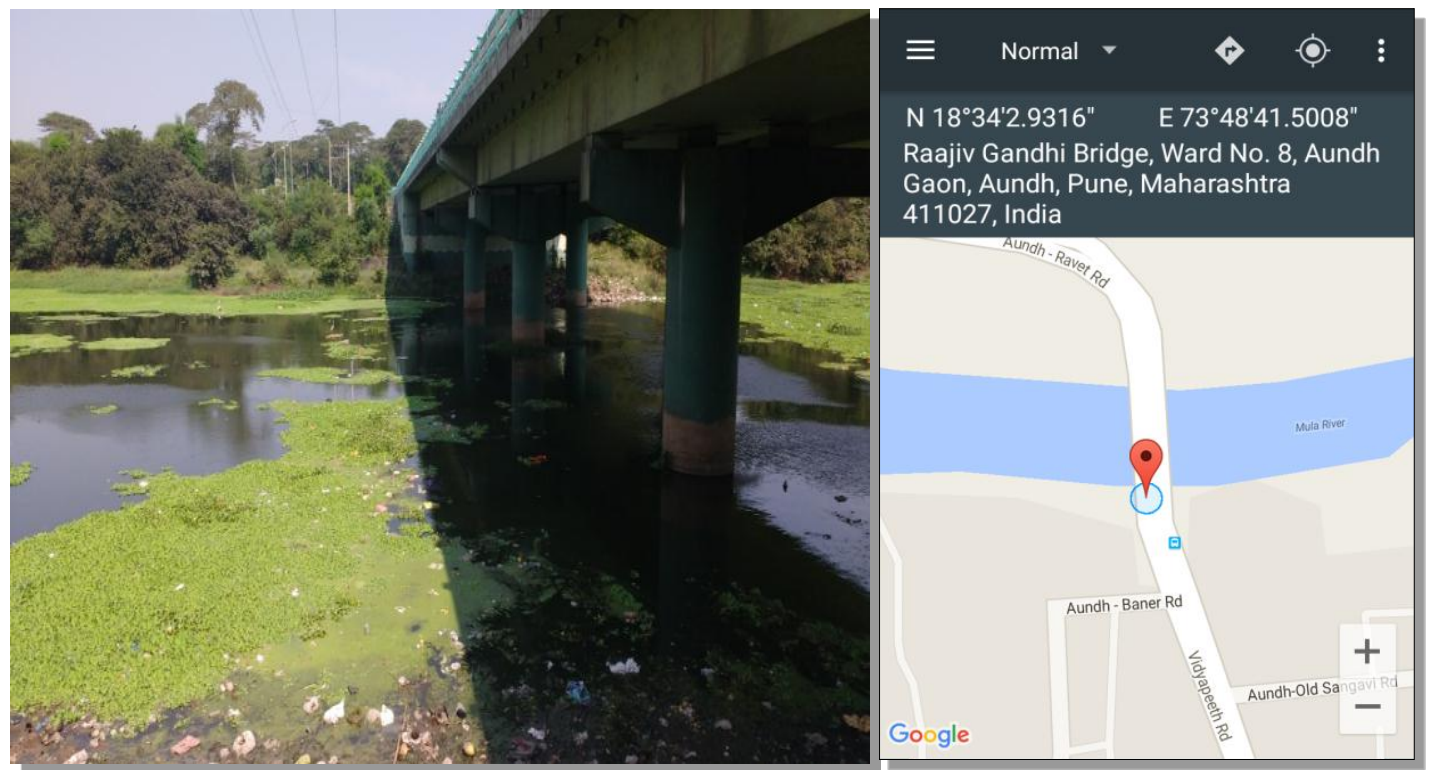

Figure 2:- Water sample collection site at Aundh - Mula River. 


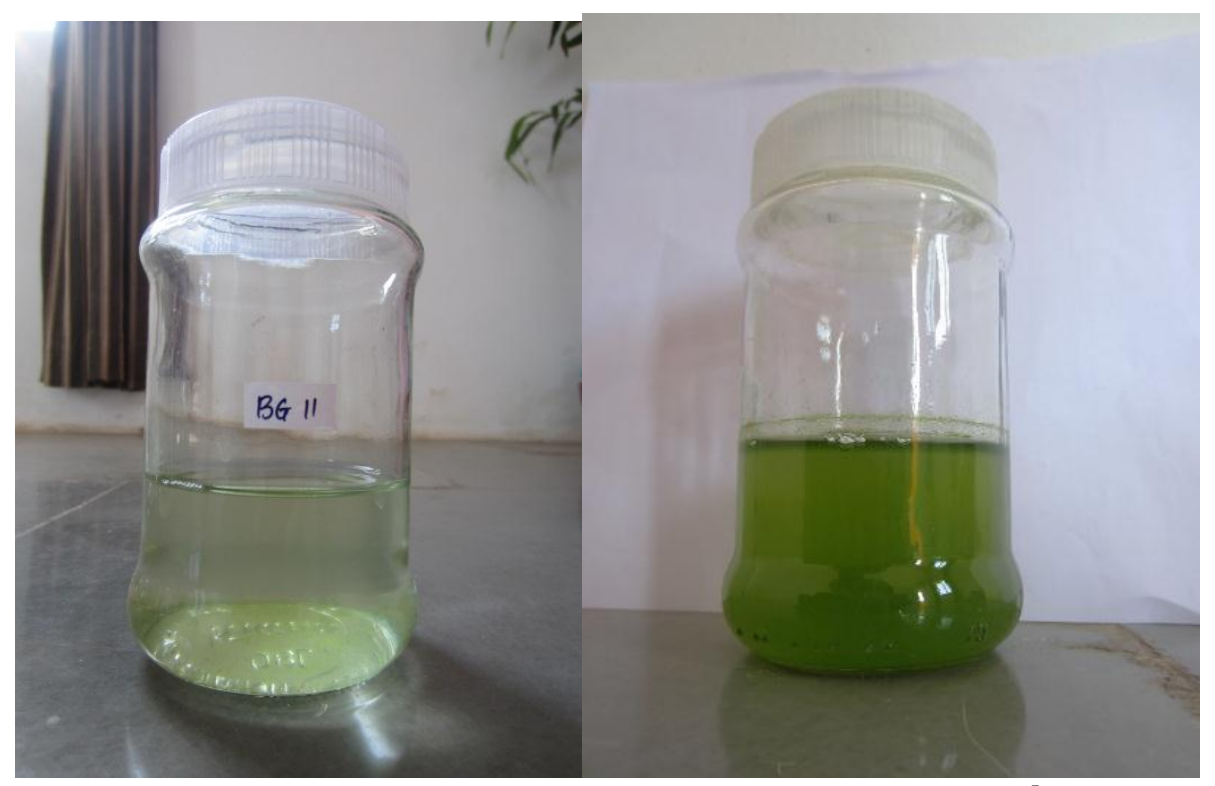

a.

b.

Figure 3:- Enrichment of algae a. Day 0; b. Day 20.

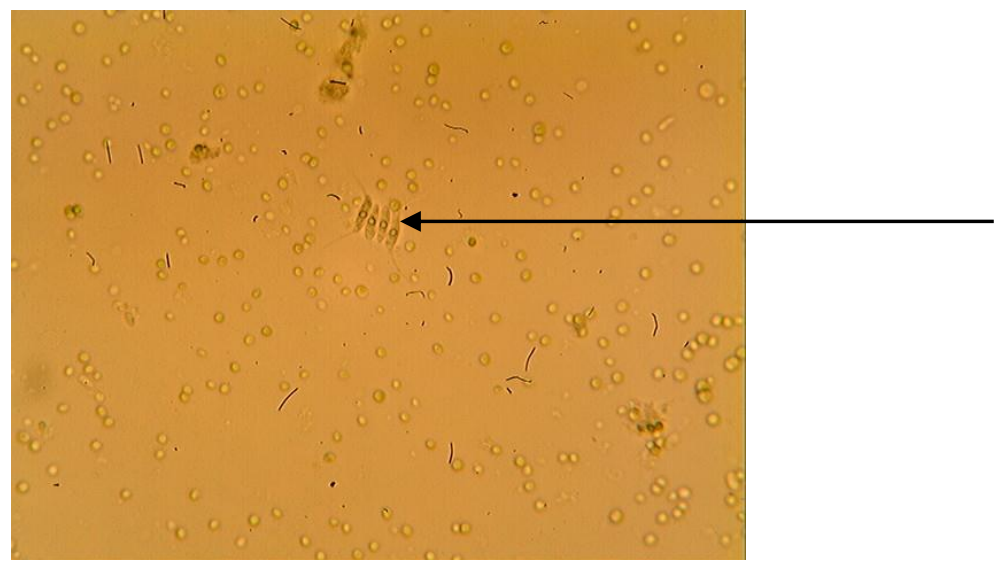

Scenedesmus spp.

Figure 4:- Microscopic field under 40X magnification. 


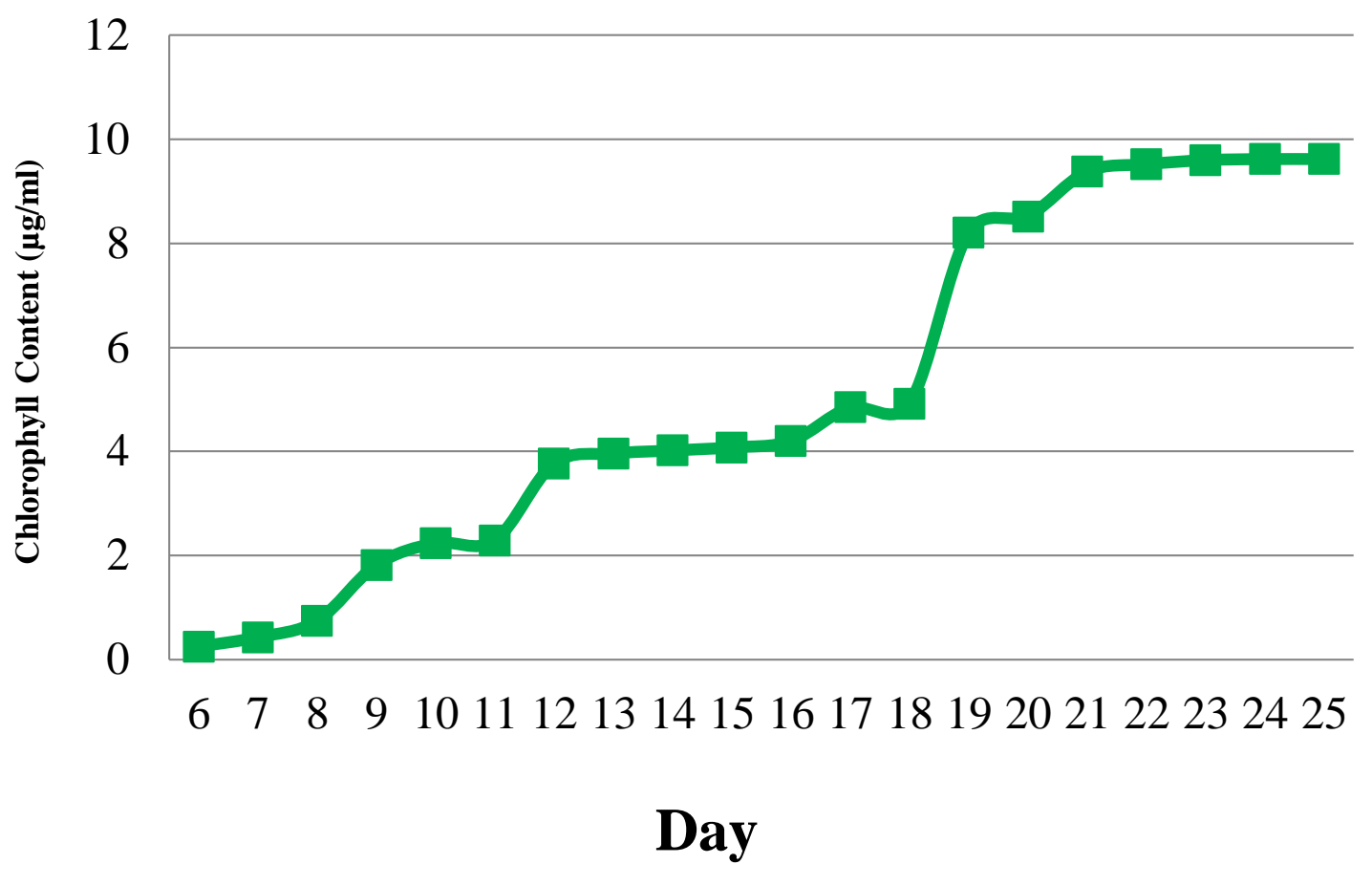

Figure 5:- Growth analysis of Algae.

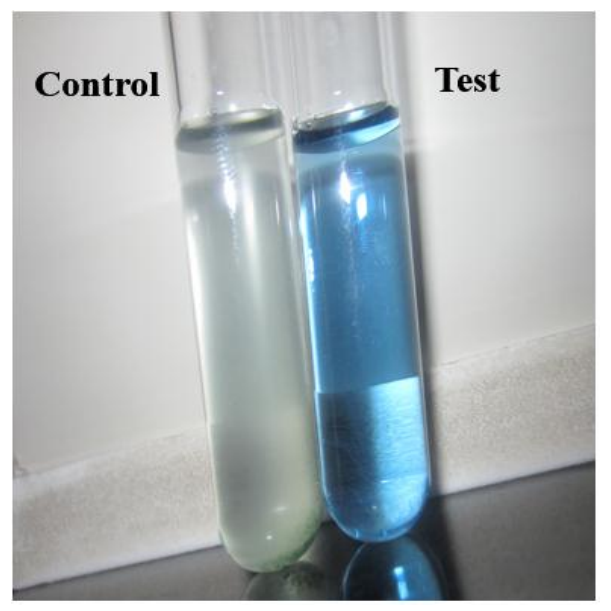

Figure 6:- Comparison between Janus Green B Test and Control. 


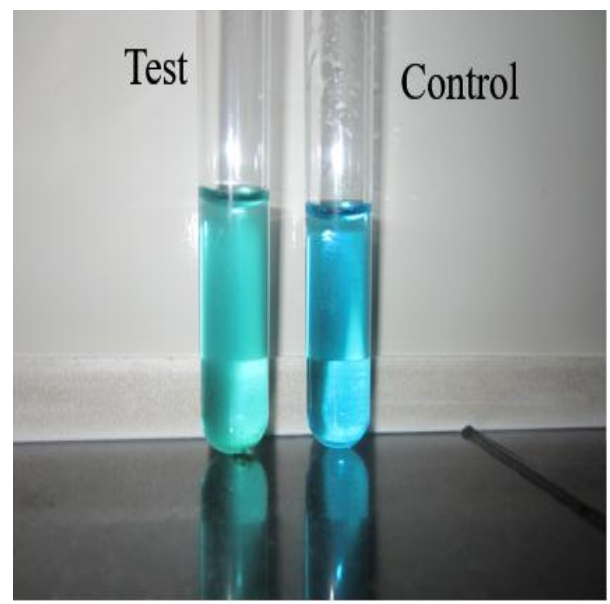

Figure 7:- Comparison of Methylene blue reduction test between Test and Control.

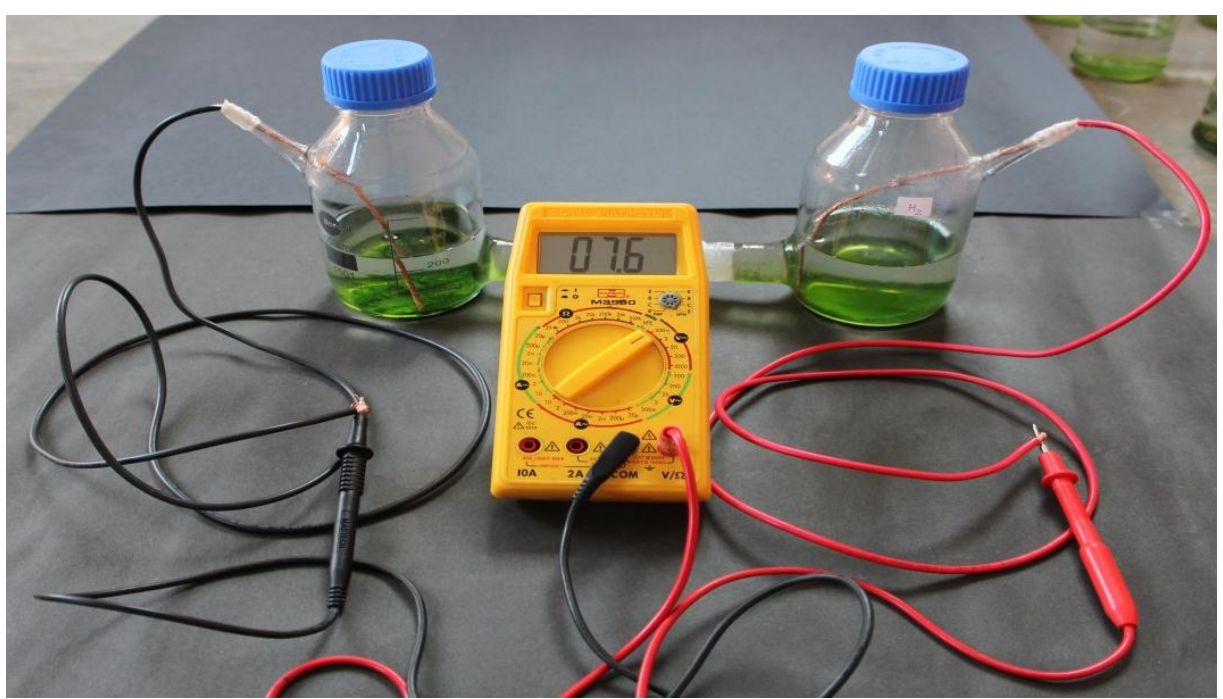

Figure 8:- Monitoring the potential difference produced in MFC. 


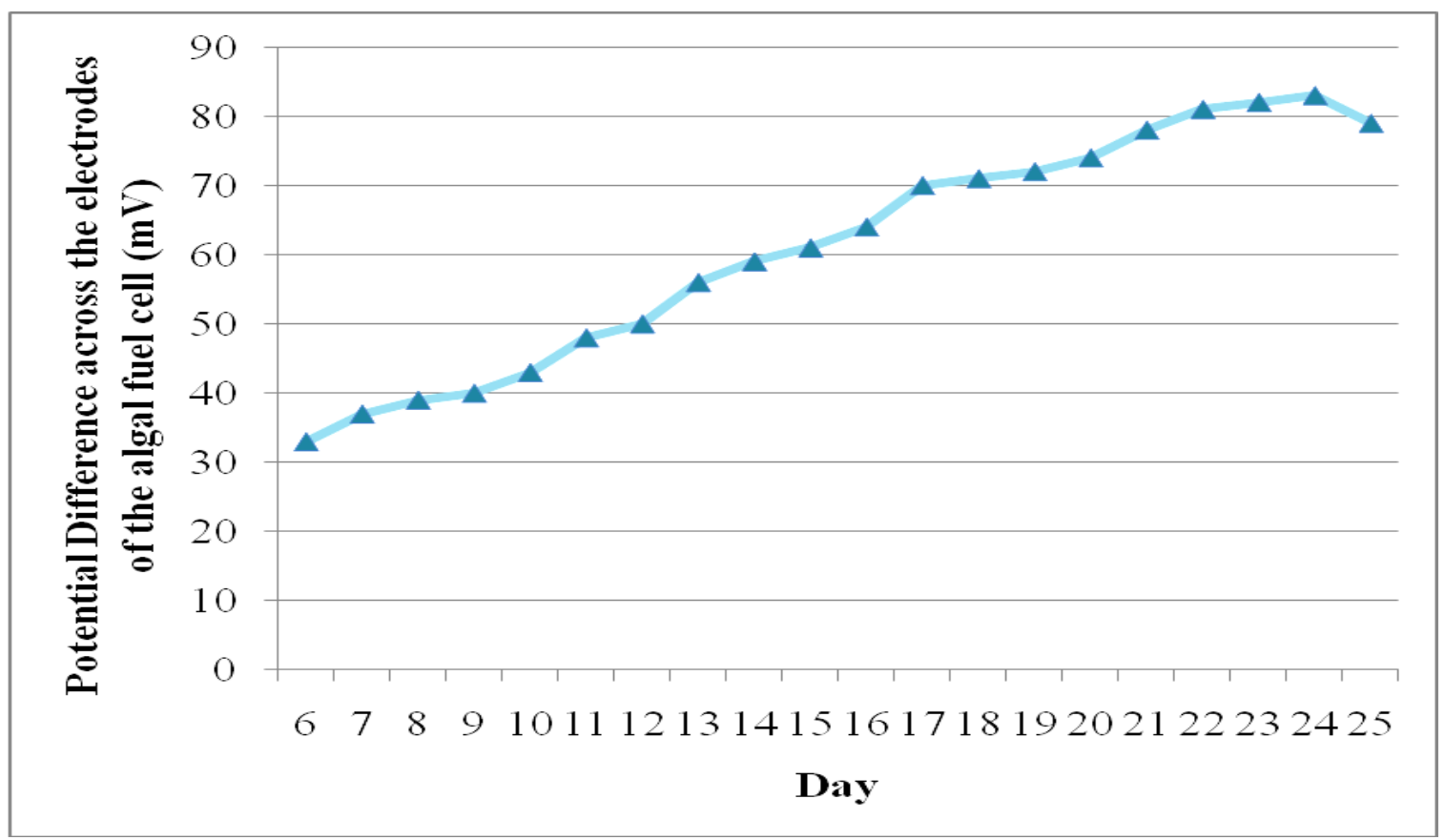

Figure 9:- Potential difference in MFC with Algae growing in BG11 media.

\section{Results and Discussion:-}

\section{Sample Collection:-}

Algal samples were collected from a fish pond and Mula River near Aundh, Pune, India since these sites showed visible growth of algae. Photographs and site coordinates are given in the images. Microscopic examination of these water bodies revealed various types of algae residing in water samples. Observation of the water samples showed consortium of green algae. However the cell density was very low. It was observed that in both the water samples Scenedesmus spp were present in abundance. The thylacoid-like arrangement of cells helped in easy identification of Scenedesmus spp. (Reda et al., 2011).

\section{Enrichment of Algae:-}

The water samples showed presence of algae but the number of algal cells present was few and hence the sample was enriched to increase growth. The sample showed visible growth of algae after $7^{\text {th }}$ day and were further incubated till maximum growth was achieved. Approximately after $20^{\text {th }}$ day the sample was again observed under microscope and it was found that the enriched sample had Scenedesmus spp.

Sudarat Chaichalerm and co-workers (2012) developed different techniques to isolate different strains of algae from natural habitats such as soil and water using various enrichment media. They also found out that many algae including Scenedesmus accumulate highest amount of lipids when grown in BG11 medium.

\section{Microscopic observation of enriched culture:-}

On microscopic observation of the enriched culture showed large proportion of Scenedesmus spp of green algae.

\section{Growth analysis of Algae:-}

Algal cells have a tendency to be unevenly distributed in culture suspension; direct enumeration methods were not suitable for growth pattern analysis of the algae. Hence another parameter like total Chlorophyll content was measured. The total amount of Chlorophyll content of the culture is directly proportion with the number of cells present in the culture. The maximum Chlorophyll content was observed to be $9.62 \mu \mathrm{g} / \mathrm{ml}$ on $24^{\text {th }}$ day. Marisol Felip et. al. in a similar study found that there is a correlation between algal biomass and the Chlorophyll content with a correlation coefficient of 0.66 . They observed that Chlorophyll content per unit of phytoplankton biovolume fluctuated greatly throughout the year, depending on light intensity, temperature and phytoplankton composition (Marisol and Jordi, 2000). 


\section{Screening for Oxygen production:-}

All types of algal cells produce Oxygen by photolysis of water during the process of photosynthesis. Janus Green B is a Redox indicator dye which turns blue in presence of Oxygen and in its reduced forms the dye turns pink in colour. The Janus Green B dye changes its color from colorless to blue indicating oxidation of the dye. This color change indicates presence of Oxygen.

\section{Screening for Hydrogen production:-}

The Hydrogen producing capacity was tested using MBRT test wherein the reduction of dye was observed due to presence of Hydrogen. The redox indicator dye Methylene blue got reduced changing from blue to colorless. This is evidence of Hydrogen production by the culture.

Anastasios Melis et. al in their study discussed the photoproduction of Hydrogen by green algae under Sulphurdeprived conditions. The mechanism of Hydrogen production was elaborated and it was estimated that under ideal conditions of nutritive media and light intensity maximum yield of $\mathrm{H}_{2}$ production by green algae can be $10 \mathrm{~mol} \mathrm{H}_{2}$ $\mathrm{m}^{-2} \mathrm{~d}^{-1}$. The study further discussed Hydrogen production by C. reinhardtii (Anastasios and Thomas, 2001).

\section{Construction of fuel cell and Monitoring potential difference produced in MFC:-}

The fuel cell was initially constructed using algal samples growing in Sulphur deprived and normal BG11 media. A salt bridge was constructed using $1 \mathrm{~N} \mathrm{KCl}$ and it was used to connect both the chambers. The assembly was incubated in bright sunlight and the potential difference across the electrodes was measured after equal intervals of time. The maximum potential difference observed was $83 \mathrm{mV}$ on $24^{\text {th }}$ day.

A study conducted by Yong Yuan and co-workers suggests that the algal fuel cells can be efficiently used for power generation as high as $114 \mathrm{~mW} / \mathrm{m}^{2}$ at a current density of $0.55 \mathrm{~mA} / \mathrm{m}^{2}$ and for waste water treatment by removal of as much as $78.9 \%$ of total chemical oxygen demand and $91.0 \%$ of total Nitrogen (Yong, 2011).

In another study conducted by David P. B and co-worker indicates that the algal fuel cell produces more electricity as compared to the microbial fuel cell. The maximum electricity produced by the algal fuel cell in this study was noted to be $539 \mathrm{~mA}$ and hence was said to be a renewable and sustainable method of electricity production (Hubertus and Cees, 2008).

\section{References:-}

1. Ali, M.S., Kamarudin, S.K., Masdar, M.S., Mohamed A. (2014): An Overview of Power Electronics Applications in Fuel Cell Systems: DC and AC Converters. The Scientific World Journal, Hindawi Publishing Corporation, 1-9.

2. Anastasios, M., Thomas, H. (2001): Hydrogen Production. Green Algae as a Source of Energy. Plant physiology, 127: 740- 748.

3. Berliner, M.D., Reca, M.E. (1967): Vital staining of Histoplasma capsulatum with Janus green B. Sabouraudia: Journal of medical and veterinary mycology, 5(1): 26-29.

4. Chang, X., Karen P., Martin M.F.C., Ruihua, W. (2015): Using live algae at the anode of a microbial fuel cell to generate electricity. Environ Sci Pollut Res, DOI 10.1007/s11356-015-4744-8.

5. Chatterjee, S. N., Bhattacharjee, I., Chatterjee, S.K., Chandra, G. (2006): Microbiological examination of milk in Tarakeswar, India with special reference to coliforms. African Journal of Biotechnology, 5(15): 13831385 .

6. Das, K., Sharma, G.C. (2015): Optimization of culture media for the growth of Anabaena spiroides and Nostoc punctiformae of Jorhat district, Assam. IOSR Journal of Pharmacy and Biological Sciences, 10(2): 3741.

7. Dere, S., Güneş, T., Sivaci, R. (1998): Spectrophotometric Determination of Chlorophyll - A, B and Total Carotenoid Contents of Some Algae Species Using Different Solvents. Tr. J. of Botany, 22: 13-17.

8. Dimitris, K.N., Maria, D. (2016): Fuel cells are a commercially viable alternative for the production of “clean" energy. Ambio, 45(1): S32-S37.

9. Gaffron, H. (1939): Reduction of $\mathrm{CO}_{2}$ with $\mathrm{H}_{2}$ in green plants. Nature, 143: 204-205.

10. Hubertus, V.M.H., Cees, J.N.B. (2008): Renewable sustainable biocatalyzed electricity production in a photosynthetic algal microbial fuel cell (PAMFC). Appl Microbiol Biotechnol, 1-10. 
11. Marisol, F., Jordi, C. (2000): The relationship between phytoplankton biovolume and Chlorophyll in a deep oligotrophic lake: decoupling in their spatial and temporal maxima. Journal of Plankton Research, 22(1): 91105 .

12. Olle, I., Villy, S. (2016): Solar energy for electricity and fuels. Ambio, 45 (1): S15-S23.

13. Reda, A.I., Ibrahim, A.S., Su-Nam Kim, A.M., You-Kwan, Oh., Jaeyoung, C., Byong-HJ. (2011): Characterization and identification of lipid-producing microalgae species isolated from a freshwater lake. Biomass and Bioenergy, 35: 3079-3085.

14. Stanier, R. Y., Kunisawa, R., Mandel, M., Cohen-Bazire, G. (1971): Purification and Properties of Unicellular Blue-Green Algae (Order Chroococcales). Bacterological Reviews, 35(2): 171-205.

15. Sudarat. C., Prayad, P., Wenqiao, Y. (2012): Culture of microalgal strains isolated from natural habitats in Thailand in various enriched media. Applied Energy, 89: 296-302.

16. Williams, C. R., Bees, M.A. (2013): Mechanistic Modeling of Sulfur-Deprived Photosynthesis and Hydrogen Production in Suspensions of Chlamydomonas Reinhardtii. Biotechnology and Bioengineering, 111(2): 320335.

17. Yong, Y., Qing, C., Shungui, Z., Li Z., Pei, H. (2011): Bioelectricity generation and microcystins removal in a blue-green algae powered microbial fuel cell. Journal of Hazardous Materials, 187: 591-595. 